\title{
MAIS VALE UM J EGUE QUE ME \\ CARREGUE QUE UM CAMELO QUE ME DERRUBE, LÁ NO CEARÁ...
}

Rosa Magalhães

A carnavalesca Rosa Magalhães destaca algumas questões importantes do processo de criação para o carnaval de 1995 da escola de samba Imperatriz Leopoldinense, desde o surgimento da ideia para o tema até a solução para vicissitudes acorridas no momento do desfile, passando pelas propostas plásticas adotadas para a criação dos diferentes setores da escola.

CARNAVAL, ESCOLADESAMBA, ENREDO, IMPERATRIZ LEOPOLDINENSE, ALEGORIAS, FANTASIAS 


\section{A VIAGEM}

O camelo sempre foi um dos bichos que mais me atraíram. Muito feio, diga-se de passagem, tem duas corcovas, os joelhos pontudos, as patas parecem grandes demais para os cambitos, é beiçudo e ainda por cima tem dois estômagos. Tudo parece não combinar. Achei que montar um desses animais seria fácil, pois, com duas corcovas, era só se encaixar no meio e os dois protetores naturais evitariam a queda. A minha experiência foi bem diferente. No Marrocos, depois de exaurir todas as possibilidades de conhecer museus e monumentos, mercados, lojas e palácios, o meu guia, Faté, tal qual o gênio da lâmpada, perguntou o que mais eu gostaria de fazer. "Andar de camelo" foi a resposta imediata. Já vinha ensaiando o pedido fazia tempo. Fomos para a estrada que margeia o deserto de Saara e lá, debaixo de uma palmeira, havia dois ou três camelos à espera de fregueses. Escolhi um, o tratador o fez ajoelhar-se, ele obedeceu a tudo direitinho. Mas só tinha uma corcova. Meu espanto foi saber que era ali mesmo, bem em cima daquele "calombão", que eu deveria sentar, numa sela quase inexistente. A vontade, porém, era maior que o medo. Sentei, segurei a rédea e o bicho começou a se levantar. Foi horrível, primeiro ele esticou as duas pernas traseiras, e a minha cara foi beijar o chão, depois levantou as da frente, e lá fui eu pra trás. Vi o céu sem fazer esforço. Quando ficou de pé, fui para as alturas, porque um camelo é um bicho muito, mas muito alto mesmo. No começo, chacoalhou um bocado e o tratador, para minha segurança, ia correndo junto; mas depois, já no galope, foi emocionante. Lá estava eu, em pleno deserto do Saara, montada num camelo, galopando.

Quando li sobre a viagem que Gonçalves Dias fez até Baturité ${ }^{1}$, no final do século $\mathrm{XIX}$, em cima de um desses animais, pude imaginar a sua vontade e curiosidade de usar aquela montaria. No entanto, até saber de todos os fatos sobre essa primeira expedição científica brasileira, tive de ir atrás de muitas informações. Meu pai mencionou, certa vez, a existência de camelos no Ceará, mas não entrou em detalhes. No Instituto Histórico e Geográfico Brasileiro, não encontrei notícias muito precisas sobre o assunto.

Assim, por algum tempo, a história dos camelos ficou no limbo, à espera de novas fontes. Foi por acaso que acabei achando o que procurava. Marquei um encontro com um entomólogo, professor da UFRJ, e ele escolheu o local: a biblioteca da universidade, na Quinta da Boa Vista. Como não conhecia o lugar, tratei de ir mais cedo. A biblioteca era no fim de um caminho lateral todo arborizado. A bibliotecária já estava avisada de que eu chegaria e começamos a conversar sobre o material ali arquivado. Para minha surpresa, era exatamente onde todas as expedições científicas brasileiras tinham seu registro, inclusive essa primeira. Lá mesmo, dias depois, fiz toda a pesquisa. Alguns livros não puderam ser copiados por causa de sua raridade, mas através de um colecionador cearense consegui o que me faltava, inclusive um livreto que ensina como tratar de dromedários adultos e de filhotes. 
E foi assim que entrei em contato com esses camelos que me renderam um bom enredo para o desfile da Imperatriz Leopoldinense no carnaval de 1995: "Mais vale um jegue que me carregue que um camelo que me derrube, lá no Ceará..."

A história narrada no desfile da escola de samba falava sobre a expedição organizada por Dom Pedro II, para a exploração do Nordeste. O grupo encarregado desta tarefa foi a Paris para a compra de livros e instrumentos científicos. Ficou lá dois anos. O navio da marinha brasileira que devia trazer a expedição ao Nordeste quebrou e tiveram que alugar outro barco. Chegando ao Ceará não encontraram o solo apenas arenoso, mas com pedriscos, completamente impróprio para os camelos que haviam sido importados da Argélia juntamente com seus tratadores. Foi por isso que Gonçalves Dias caiu do camelo. E depois de todas essas aventuras, o relatório final sumiu, dizem que sumiu num naufrágio, será?

Fiz a divisão do enredo em quatro partes: (1) a organização da expedição, o sonho do Eldorado, a partida; (2) a Argélia, onde foram comprados os dromedários, (3) a viagem pelo Ceará e, finalmente; (4) a homenagem ao jegue.

Como o enredo abordava a região nordestina do Brasil, fiz uma fusão dos elementos decorativos e das peças de vestuário árabe com os elementos visuais característicos do Ceará, como as rendas, os retalhos, as fitas dos trajes folclóricos, as bruxas de pano, os mamulengos, além de flores em relevo e fuxicos².

Dos árabes, fui buscar as jóias vistosas, com pedrarias e muita prata, que são vendidas a peso no mercado. Também foram incluídos a ornamentação preciosa e rebuscada, o colorido dos tapetes - cujos fios são tingidos e postos para secar pelas ruas das cidades, formando enormes franjas nos tons mais variados -, além dos animais, que fazem a festa nas praças.

Ainda nas minhas andanças pelas bandas orientais, lembrei-me de um mercador que cobrava para mostrar o que havia dentro da sua cesta. Muito curiosa, paguei as moedas que me pediu enquanto ele abria a cesta que trazia no braço. Conforme foi abrindo a cesta bem devagar, fui chegando o rosto mais para perto da tampa já entreaberta, cheia de curiosidade. Dei um grito de pavor quando, lá de dentro, saiu uma enorme cobra preta, daquelas com uma espécie de aba na cabeça que a faz parecer ainda maior. O mercado, as cobras nas cestas e os ursos com argolas no nariz foram transformados em carro alegórico.

O camelo e o jegue convivem também naquele pedaço de terra. Talvez por uma dessas coincidências, fiz ainda um passeio de jegue, não por gosto, mas por pura necessidade.

A cidade de Fez ainda conserva suas muralhas e as casas são muito juntas, para minorar o calorão. Foi visitando essa cidade, onde os automóveis são proibidos de circular, que completei o que ouso chamar de "meu ciclo exploratório de transportes alternativos". A pequena vila é situada numa encosta, tendo no seu topo um hotel elegante onde os carros ficam estacionados. De manhã cedo, a temperatura estava amena e 
fui descendo ladeira abaixo, olhando tudo o que podia. Às onze e meia da manhã, o sol era de lascar a temperatura já havia atingido os 40 graus. Meu guia havia me dito que ao meio-dia o calor já estaria na faixa de 46 graus e teríamos de ficar no hotel até as quatro da tarde, esperando refrescar. Quando me lembrei disso, olhei para o alto do morro e calculei a distância que já havia percorrido: um estirão de tirar o fôlego. Desanimei de voltar a pé. Neste exato momento, surgiu um menino tocando um burrico com uma varinha e gritando: "Táxi?". Um pedaço de tecido de listras coloridas amarrado na barriga do animal servia de sela... e nada mais. Rédeas, também não tinha. Depois dessa rápida análise da situação, respirei fundo e disse, cheia de certeza, "Táxi!", chamando pelo garoto. Na verdade, eu deveria sentar de lado com uma das pernas pendurada e, para guiar o jumento, era só cutucar a cabeça dele com o pé da outra perna quase esticada em cima do seu pescoço. Simples só para quem está acostumado. Montei mesmo como achei meIhor, escanchada sobre o bicho e agarrada à pouca crina do pescoço, já que a ausência de rédeas me obrigava a isso. Em vez do pé, optei pela mão, que esticava, dando a direção a seguir. E foi assim que cheguei bravamente, sob o sol escaldante do meio-dia e escoltada por uns cinco ou seis moleques, no meu abrigo refrigerado, onde me aguardava uma refeição saborosíssima.

Seria mera coincidência, anos depois, os dois animais aparecerem de novo diante de mim em circunstâncias tão diferentes?

\section{A CRIAÇÃO}

Li tudo o que consegui de material sobre eles e redigi o enredo. O título, pedi emprestado a Gil Vicente ${ }^{3}$. Com uma pequena mudança, ele traduzia toda a história a ser contada.

O enredo foi entregue aos compositores e parti para o trabalho de desenhar os trajes. Na época da expedição, o cais do porto do Rio de Janeiro de onde partiam as embarcações era um rebuliço e um burburinho só. O chafariz de mestre Valentim, que ficava ali, entrou em um dos carros alegóricos, junto com botes e vendedores de flores e frutas. A alegoria deu muito trabalho para ser executada, mas os tapetes orientais ficaram verdadeiramente lindos, com emendas e recortes que, de certo modo, remetiam ao artesanato de retalhos do Nordeste. E o Nordeste se mesclava nas rendas, nas cerâmicas populares e nos retalhos e fuxicos.

As baianas vieram de branco, com panos de renda também branca, trabalhada com cordinhas de varal de roupa e uma tela branca em vários modelos diferentes. Por cima, o pano da costa ${ }^{4}$ formado de retalhos de tecidos os mais variados, metalizados, acetinados e alguns em algodão. O pano da costa foi uma contribuição do aderecista da Imperatriz Leopoldinense, Sergio Faria, pois não fazia parte do desenho original, mas completou o traje.

A comissão de frente era uma espécie de festa folclórica, a fantasia vinha com muitas flores em relevo, fuxicos na capa, fitas e uma sombrinha que ia tendo várias utilidades no decorrer da coreografia. Foi um elemento muito trabalhoso e delicado. $\mathrm{O}$ abrir 
e fechar fazia com que, durante os ensaios da coreografia, as sombrinhas de cabos muito longos, não aguentassem e se quebrassem com muita facilidade. A maquiagem ajudava a dar um ar de bonecos de trapo aos bailarinos.

Escrevi o enredo umas três vezes e, quando estava na penúltima versão, resolvi fechar o desfile com o grito do Ipiranga, já que Dom Pedro I, naquele momento, estava montado num jegue para atravessar a parte mais íngreme da estrada, embora o quadro de Pedro Américo o retrate num fogoso corcel branco. Dei para minha mãe ler e ela anotou no manuscrito: "O final não está bom, coloque a coroa no jegue". Não resisti à critica de minha mãe, que estava coberta de razão.

E foi assim que o jegue tomou uma dimensão maior, surgindo já no abre-alas, em que vários jegues estão coroados como os grandes heróis da história. Foi por isso também que o último carro se chamou "Viva o Jegue".

A pedido de Tasso Jereissati, então governador do Ceará, convidei cearenses famosos para compor as figuras do carro alegórico, como Renato Aragão, Tom Cavalcanti e Fagner.

\section{O DESFILE}

O desfile oficial das Escolas de Samba, a ser analisado pelos jurados, começa exatamente numa linha amarela, traçada uns cinquenta metros depois da curva de entrada para o Sambódromo.

Justo o carro que representava a viagem dos camelos, um barco cheio de escotiIhas por onde saíam as caras desses animais, quebrou imediatamente antes de entrar na pista de desfile, em frente ao primeiro recuo da bateria. Em poucos segundos, as pessoas que estavam à volta e que viram a aflição dos empurradores levantaram aquele peso enorme, de toneladas, e, como que por milagre, o barco sumiu no recuo, sem que isso causasse nenhum problema nem prejudicasse a apresentação da escola no seu todo. No final do desfile, ouvi de um diretor: "Fomos muito bem". Mostrei a ele o carro quebrado, que lá de longe só deixava ver o braço de um boneco como que acenando para nós. Apesar disso, a escola ganhou o primeiro lugar. Na realidade, aquele carro não fez tanta falta assim, pois, na época, o regulamento não falava sobre a ausência de alegorias durante o desfile e só sugeria punir com perda de pontos caso o enredo não estivesse claro. Atualmente, nesse item de julgamento, os jurados são obrigados a tirar alguns décimos da pontuação caso falte um dos carros descritos na sinopse, não importando se a história foi bem contada ou não. O jegue e o camelo escaparam ilesos dessa vez. E, naquele ano, a escola foi bi-campeã do carnaval.

\section{NOTAS}

1 Cidade do interior do Ceará.

2 Significando inicialmente qualquer tipo de remendo mal feito, o termo "fuxico" passou a ser usado, atualmente, para denominar pequenas peças de retalho trabalhadas em forma circular, geralmente unidas para formar uma espécie de colcha de retalhos. 
3 "Mais vale asno que me carregue, que cavalo que me derrube" é uma famosa fala de uma personagem da obra $A$ farsa de Inês Pereira, de Gil Vicente, teatrólogo português do século XV.

4 Parte integrante da indumentária das baianas de escola de samba, consistindo numa grande faixa de pano presa ao ombro, geralmente esquerdo. Referência ao pano-dacosta, ou pano das costas, característico das "baianas" que ocupavam as ruas das grandes cidades brasileiras no século XIX, comercializando uma grande sorte de "quitandas".

Rosa Magalhães é Professora Adjunta da Escola de Belas Artes da Universidade Federal do Rio de Janeiro e carnavalesca. 